\title{
Sejarah Film Pendek Animasi
}

\author{
Budiman Akbar \\ @axbarock@yahoo.com \\ Politeknik Negeri Media Kreatif Jakarta \\ Jl. Srengseng Sawah, Kec. Jagakarsa - Jaksel
}

\begin{abstract}
Abstrak
Animasi merupakan salah satu bentuk film, selain fiksi, dokumenter dan eskperimental. Meski menjadi bagian dari keilmuan film, namun animasi juga dapat berdiri sendiri sebagai bentuk keilmuannya. Oleh karenanya diperlukan materi-materi pembelajaran yang sesuai, termasuk sejarah film animasi itu sendiri. Meski cakupannya dalam durasi film merupakan bentuk film pendek. Hal yang tentunya juga dipertanyakan terhadap durasi tersebut, mengingat dalam periode awal film tidak ada film yang di produksi lebih dari lima menit. Setidaknya eksistensi film animasi dalam dunia perfilman dapatlah terlihat dengan jelas melalui sejarah film animasi. Melalui pengumpulan data dari beberapa sumber, terurai bagaimana proses produksi film animasi dimulai dengan teknik yang sangat rumit dan membutuhkan waktu pembuatan yang lama, hingga diciptakannya metode dan teknik serta peralatan yang lebih sederhana dan semakin mudah sebagai jembatan dalam mengatasi persoalan waktu pembuatan tersebut. Meski terbatas hanya sejarah dalam pembuatan film animasi pendek.
\end{abstract}

Kata kunci: Animasi, Film dan Sejarah

\section{Pendahuluan}

Tidak banyak yang mengulas tentang sejarah film dunia. Meski terbilang bahwa film merupakan seni terakhir dan peristiwa penciptaan pertama kalinya juga seumur satu abad lebih, sehingga dapat dibilang masih rentan waktu yang tidak terlalu jauh dari kehidupan sekarang ini. Namun persoalannya Sejarah film penuh dengan misteri, ketidakpastian, kebingungan, pertentangan dan sebagainya. Meski cinematographe diakui sebagai kamera yang sekaligus juga sebagai proyektor pertama di dunia, namun belakangan pembuktianpembukti sejarah yang lainnya terhadap kamera dan proyektor itu sendiri sekarang ini masih dipertentangkan dan diperdebatkan, khususnya terhadap proses pencapaiannya. Hal ini disebabkan antara lain adanya rasa nasionalisme atau kebanggaan nasional (baik itu politik, maupun ideologi). Para ahli sejarah atau seorang penulis pun, juga tidak luput melakukan kesalahan dengan menulis ulang catatan sejarah yang tidak obyektif. Meski akhirnya ada juga yang memperbaharuinya kelak. Disamping juga data-data industri ataupun data-data personal yang terlibat produksi film kenyataannya menghilang ataupun ada, namun sudah usang dan tidak dapat dipergunakan sebagai bukti otentik, dan sebagainya.

Perkembangan akan keilmuan sejarah film pun tidaklah sebesar dan seramai bidang lainnya. Sehingga proses untuk mencapai kesempurnaan ilmu sejarah film atau animasi pun menjadi sangat lamban. Sehingga beberapa persoalan tersebut menjadikan pendidikan dan pengajaran dalam bidang film, terutama dalam hal ini adalah film animasi menjadi sedikit mengalami kendala dalam keilmuan sejarah. Meski sekarang ini hal tersebut sudah dapat diatasi dengan mulai menggeloranya kajian-kajian ataupun ulasana-ulsana serta buku-buku terhadap sejarah film yang di terbitkan dan disebarluaskan, khususnya animasi. 
Namun kendala disini sebenarnya tidaklah berbeda jauh dengan apa yang terjadi di dunia, bahkan dapatlah dikatakan malah tertinggal jauh. Karena minat masyarakat terhadap bidang film itu sendiri pun terbilang baru beberapa tahun belakangan ini diperhatikan masyarakat tanah air. Setidaknya setelah era reformasi keterbukaan masyarakat terhadap dunia seni begitu terasa, termasuk seni film dan animasi. Oleh karenanya dibutuhkan upaya untuk memperbanyak literatur-literatur ulasan dan tulisan tentang film dan animasi itu sendiri. Salah satunya sejarah film animasi.

\section{METODE}

Penelusuran data penelitian dilakukan dengan cara mengambil dari beberapa sumber tertulis yang telah diterbitkan, seperti buku. Beberapa sumber tersebut kemudian ditelusuri dan dikumpulkan dalam tema yang sama, untuk kemudian di analisa agar mendapatkan kesamaan situasi dan kondisi terhadap karya filam animasi tertentu yang dianggap berkaitan dengan topik penelitian. Penelitian kepustakaan atau kajian literatur (literature review, literature research) merupakan penelitian yang mengkaji atau meninjau secara kritis pengetahuan, gagasan, atau temuan yang terdapat di dalam tubuh literatur berorientasi akademik (academic-oriented literature), serta merumuskan kontribusi teoritis dan metodologisnya untuk topik tertentu. 126 Fokus penelitian kepustakaan adalah menemukan berbagai teori, hukum, dalil, prinsip, atau gagasan yang digunakan untuk menganalisis dan memecahkan pertanyaan penelitian yang dirumuskan. Adapun sifat dari penelitian ini adalah analisis deskriptif, yakni penguraian secara teratur data yang telah diperoleh, kemudian diberikan pemahaman dan penjelasan agar dapat dipahami dengan baik oleh pembaca.

Pendekatan yang digunakan dalam penelitian ini adalah pendekatan filosofis dan pedagogis. Pendekatan filosofis merupakan pendekatan yang dilakukan untuk melakukan penalaran dan penyusunan suatu data secara sistematis berdasarkan sudut pandang tertentu (dalam hal ini sudut pandang yang digunakan adalah sudut pandang sejarah dalam pembelajaran). 127 Sedangkan pendekatan pedagogis merupakan pendekatan untuk menjelaskan data secara lebih rinci dengan menggunakan teori peletakan genetic moment sejarah dalam pembelajaran.

\section{PEMBAHASAN}

\section{Dari Bayangan Menuju Gambar}

Periode sebelum kehadiran film, adalah sebuah proses panjang kebudayaan dan pengetahuan manusia terhadap film. Manusia terpesona bagaimana cara kemunculan burung dan hewan pada dinding yang diwujudkan dalam bayangan yang dibentuk oleh jari-jari tangan kita dengan sorotan cahaya. Bahkan kadangkala dikombinasikan dengan cerita, yang sebenarnya, jika dihubungkan dengan permainan bayangan tersebut, kenyataannya permainan ini sudah dikenal orang jauh sebelum masehi. Wayang adalah bukti adanya permainan bayangan yang dibumbuhi dengan cerita tertentu, hadir di masyarakat sebagai tontonan dan hiburan malam hari yang pencapaiannya diyakini jauh

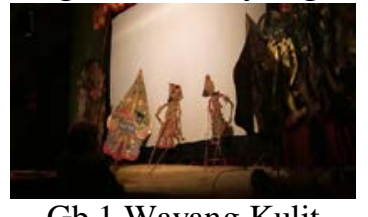




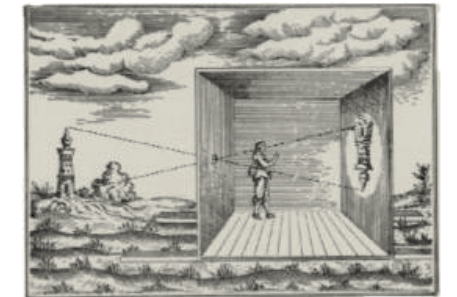

Gb 2 Mo Ti merefleksikan gambar pada abad ke-4 sebelum masehi. sebelum masehi. Bayangan menjadi hal yang penting dalam hal menciptakan visual tertentu. Lalu permainan bayangan ini berkembang, dari sorotan cahaya di malam hari, diubah oleh Mo Ti filusuf Tiongkok, pada kurun waktu sekitar 4 abad sebelum masehi, yang mampu menampilkan gambar dengan bantuan dari proses sinar matahari, dimana sinar matahari masuk ke sebuah kotak besar berkisar melebihi manusia berdiri dan memiliki lubang di salah satu sisinya sebagai jalan masuknya cahaya. Dengan metode yang hampir sama, seorang ahli matematika

Persia, Abu Ali Hasan Ibnu Al Haytem atau dikenal juga dengan Alhazen pada abad ke-10 menyederhanakannya karena saat itu juga dianggap sebagai pengetahuan cahaya dan lensa, (Kernan, Digital Cinema 1:2) dengan prinsip bayangan muncul dalam sebuah kotak yang kedap cahaya dimana gambar direfleksikan pada sehelai kain yang digantung pada sebuah rungan dan menjadi hiburan yang dipertontonkan ke khalayak.

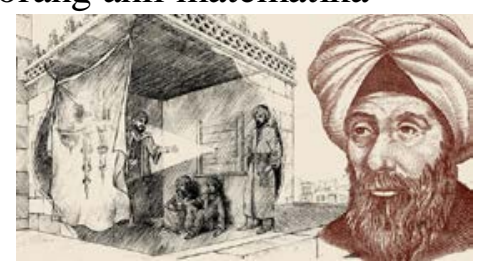

Gb 3 Abu Ali Hasan Ibnu Al Haytem pada 600 masehi

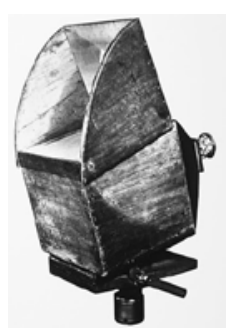

Gb 4 Camera Obscura

Kehadiran dari Camera Obscura di tahun 1611 milik Johannes Kepler astrolog/astronom dari Jerman, dipandang sebagai sebuah bentuk perkembangan yang efektif untuk mempermudah proses bayangan menuju gambar. Sebuah ruangan yang besar milik Mo Ti dan Alhazen, diubahnya menjadi kotak kecil yang dikenal dengan kamera -kata yang berasal dari chamber, yang berarti kamar atau ruangan. Kamera memberikan dampak yang signifikan, karena sangat mudah untuk dibawa kemana saja, dan membuat kita terpesona oleh daya tipu visual, ilusi optik, khayalan, dan misterinya.

Pemikiran manusia dalam permainan bayangan selanjutnya telah melahirkan teori untuk menciptakan gambar melalui bayangan, sehingga teknologi baru pun hadir. Hal itu pada akhirnya mendapatkan pencapaiannya yang diselesaikan oleh Joseph Nichopore Niepce penemu asal Perancis dengan teknik heliography pada sekitar tahun 1826 yang menghadirkan
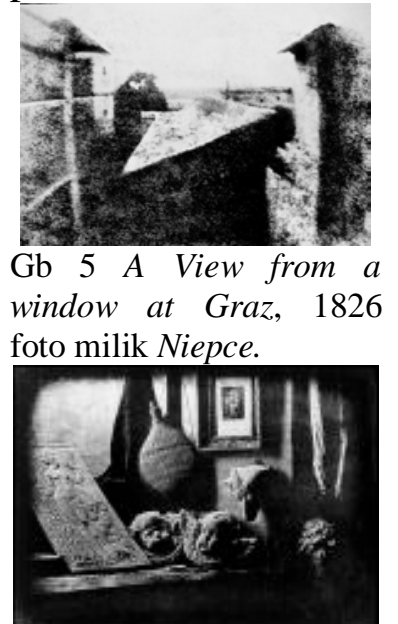

Gb 6 Still Life in The Artist's Studio 1837 foto hasil dari Daguerretype milik Daguerre. fotografi sebagai teknologi yang mampu merekam dan mencetak gambar. Meski pada kehadiran pertamanya, gambar yang dihasilkan fotografi Niepce tidak setegas dan sejelas kerabatnya Louis Jacques Mande Daguerre dengan alat yang dikenal sebagai Daguerretypenya, namun hasil Niepce ini disepakati sebagai yang pertama. Namun diantara mereka berdua belum dianggap merepresentasikan hasil yang diinginkan, karena untuk mencetak foto mereka, membutuhkan waktu yang cukup lama. Niepce malah membutuhkan waktu sekitar 8 jam pada foto pertamanya.

Sehingga kehadiran Talbottype dari Henry Fox Talbot dengan kemampuannya dalam mencetak gambar lebih cepat, persoalan bahan baku foto ini pun menyingkirkan kaca dan logam sebagai bahan baku yang digunakan sebelumnya. Talbottype menggunakan kertas negatif untuk mencetak gambar, dan memungkinkan untuk mencetak gambar foto sepersekian detik untuk digunakan pada slide lentera kaca dan proyektor. Dua syarat yang

perlu dipenuhi sebagai dasar untuk menciptakan gambar dan visual, yakni kamera sebagai peralatan yang merupakan sebuah ruangan dalam memproses bayangan dan kertas negatif 
sebagai bahan bakunya untuk materi menyimpan rekaman gambar, sebuah prinsip menuju gambar bergerak -motion picture.

\section{Periode Awal Film}

\section{A. Gambar Bergerak}

Berawal dari teori "persistence of vision“, yaitu sebuah teori yang menyatakan bahwa mata memiliki kelemahan dalam menangkap cahaya, maka beberapa kejadian memperlihatkan bahwa aspek animasi sudah digunakan dalam gambar bergerak pada era sebelum film Lumiere hadir. Ada beberapa bukti yang terdapat di dalam film yang dibuat untuk mainan proyektor di tahun 1890 (seperti permainan model Fantascope atau Zoetrope dan sebagainya), gerakannya dilakukan dari objek atau gambar dipotret secara frame by frame -satu bingkai satu bingkai- dalam satu waktu.

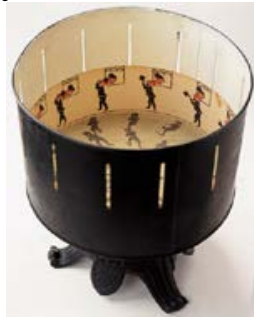

Gb 7 Zoetrope

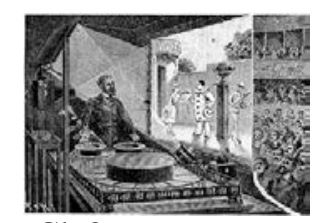

Gb 8 Parxinoscope

Dalam proses singkatnya dimulai saat Charles Emile Reynaud mampu menghadirkan gambar praxinoscope-nya untuk diproyeksikan dan merupakan pelopor penting untuk sinematik animasi. Lalu Fotografer Inggris Eadweard Muybridge dengan nama yang cukup aneh, yaitu zoopraxiscope yang menciptakan ilusi dengan lebih persuasif gerakannya

dalam memproyeksikan gambar dengan mengganti tiap gambarnya lebih cepat untuk dimunculkan ke layar dimana berasal dari foto yang dicetak dan diletakkan pada piringan kaca yang berputar. Sedangkan pada tahun sekitar 1880-an George Eastman Kodak di Amerika Serikat mempersiapkan peluncuran Kodak sebagai sebuah rol film seluloid pertama di dunia. Kamera miliknya dapat memotret still foto dengan baik karena menggunakan film seluloid sebagai bahan bakunya. Belakangan, tepatnya setahun kemudian, baru diketahui kalau Eastman membuat lubang perforasi pada film seluloid Kodak ciptaannya.

\section{B. Frame by Frame Sebagai Permulaan Animasi}

Selama bertahun-tahun, sampailah pada tahun terakhir abad kesembilan belas, para fotografer dan penemu serta pencipta di seluruh Eropa dan Amerika Serikat telah berusaha untuk dapat membuat film yang mampu mereproduksi gerak, dan pada akhirnya terhenti di sebuah kotak perekam Le Cinématographe, sebuah kotak milik Lumière Brothers (Louis dan Auguste Lumiere), dengan bahan bakunya menggunakan film 35mm milik Kennedy Laurie Dickson,

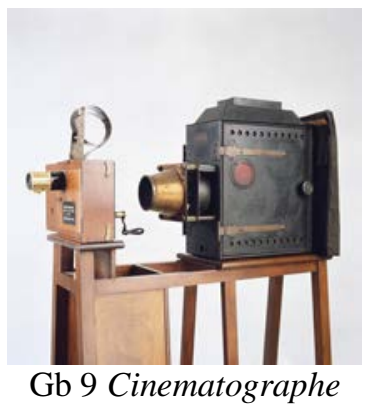
seorang asisten dari penemu termahsyur abad ke-20, Thomas A Edison, yang telah mengembangkan seluloid milik Kodak. Lumiere pun mensyut-nya filmnya pada kecepatan 16 gambar per detik. Penciptaan kamera Lumiere ini merupakan rangkaian dari penemuanpenemuan teori dan penciptaan mekanik serta materi atau bahan baku sebelumnya.

Peristiwa pada Reynaud dan Lumiere dengan cepat menarik perhatian seorang seniman vaudeville, yang diantaranya adalah J. Stuart Blackton, salah seorang pendiri Vitagraph. Sebenarnya animasi dalam industri film telah di mulai pada tahun 1906, ketika Blackton membuat bagian humor dari film Funny Faces of untuk Vitagraph. Ia menampilkan gambar, yang kebanyakan gambar wajah dengan dibuat secara frame by frame, dimana Blackton 
hanya menambahkan goresan di tiap frame-nya, lalu gambar muncul secara bertahap tapi ketika wajah melirikan matanya, gambar tidak dapat bergerak lagi sampai pada bagian akhir.

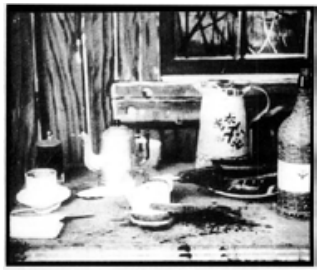

Gb 10 The Haunted Hotel

Film Blackton, The Haunted Hotel, dihadirkan melalui frame by frame saat adegan makan terihat dari dekat (close up) benda-benda yang ada di atas meja, dan secara tiba-tiba sebilah pisau yang ada di meja, dapat melayang dan bergerak sendiri untuk memotong roti dan mengoleskan mentega tanpa adanya campur tangan seseorang (1907). Sangatlah menakjubkan saat itu, karena penonton akan berpikir bagaimana dapat terjadi gerakan tersebut pada obyek atau benda dalam sebuah film live action. Padahal itu dilakukan hanya melalui beberapa

trik di film yang dilakukan Blackton seperti double-exposure, wires dan stop-motion, untuk dapat berhasil memperlihatkan sebuah kekuatan supranatural sepertinya ada di dalam Hotel. The Haunted Hotel merupakan salah satu film yang rilis dengan menggunakan Vitagraph di kantor barunya yang berada di Paris, yang kemudian banyak ditiru di luar negeri.

Pada tahun yang sama (namun ada juga yang menjelaskannya terjadi di tahun 1906), Pathe Freres (didirikan oleh Charles Pathe dari Perancis) memproduksi Le Theatre de Petit Bob (Little Bob's Theater), bersama pembuat film asal Spanyol yakni Segundo De Chomon yang objek gambarnya secara perlahan-lahan dapat bergerak untuk pindah diantara single-frame exposure, ketika Chomon membuat konten animasinya berdasarkan permainan kotak anak laki-laki agar tampak

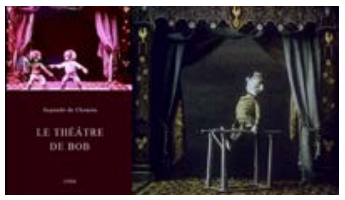

Gb 11 Le Theatre de Petit Bob (Little Bob's Theater), 1906. realistis dan terlihat lebih hidup. Animasi benda seperti itu disebut dengan pixillation.

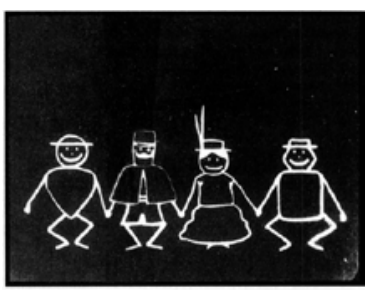

Gb 6 Fantasmagorie

Emile Cohl, yang bekerja untuk Gaumont di tahun 19081910, adalah orang pertama yang mencurahkan energinya pada animasi dengan cara menggambarnya. Kartun yang pertama kali muncul adalah Fantasmagorie pada tahun 1908. Dalam rangka menciptakan gerakan yang stabil, Cohl pun menempatkan setiap gambarnya di atas plat kaca yang diterangi lampu dari bawah dan kemudian menggambarnya pada setiap lembar kertas dengan

membuatnya sedikit perubahan pada bentuk figurnya saat menggambar di lembar berikutnya. Banyak film-filmnya menampilkan hal-hal yang aneh, mengalirkan kesadaran yang ditransformasikan kedalam serangkaian bentuk, dari satu bentuk ke bentuk yang lainnya. Cohl juga membuat film-film live-action yang adegannya sering digabungkan dengan beberapa gambar animasi. Cohl pun akhirnya pensiun membuat film saat masih remaja dan hidup dalam kemiskinan serta meninggal pada tahun 1938.

\section{Frame by Frame di Amerika Serikat}

Seorang kartunis suratkabar dan vaudevillian terkemuka Winsor Mccay juga mulai tertarik membuat film animasi, yang awalnya ditujukan hanya sebagai sebuah proyek aksi untuk pertunjukan panggung. Setelah membuat serangkaian komik (komik strip) di suratkabar dengan judul Little Nemo in Slumberland, ia pun kemudian membuat film animasi pendek pertamanya yakni Little Nemo, yang selesai pada tahun 1911, dengan menampilkan 
karakter dari komik surat kabar tersebut. Film ini mengandung prolog yang dibuat dari sejumlah gambar yang diperlukan untuk animasi dengan mencoba menunjukkan aksi hidup -live action. Pembuatan animasi ini menghabiskan sekitar empat ribu gambar, dengan durasinya selama empat menit, di bawah pengawasan Blackton. karakter Little Nemo tampil, berinteraksi, dan bermetamorfosis sesuai keinginan McCay, dan kemudian segera memperlihatkannya pada

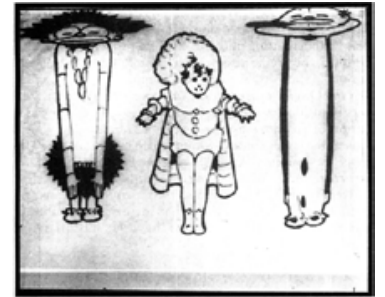

Gb 7 Little Nemo aksi panggung vaudeville-nya. Setelah keberhasilan animasi pertamanya tersebut dan dapat di terima khalayak dengan baik, McCay pun segera membuat kartun keduanya, yang berjudul The Story of a Mosquito, di tahun 1912. Seperti film pertamanya, film keduanyapun McCay menggunakan ribuan gambar, yang masing-masingnya di foto pada setiap satu bingkainya dalam satu waktu, untuk menciptakan ilusi gerakan. Namun setelah film- film yang dibuatnya di tahun 1912, McCay pun segera membuat film lagi, yang kali ini dia benar-benar menghemat tenaga dengan memanfaatkan teknik yang dibuatnya berdasarkan pengalaman film-film sebelumnya. Lalu ia menghadirkan film ketiganya yakni Gertie The Dinosaur di tahun 1914 (film yang dianggap sebagai film terkenal McCay dan sebagai langkah awal untuk animasi modern yang mengandung gambar live action dimana McCay menampilkannya setelah aksinya di panggung). Mosquito dan Gertie the Dinosaur (1914) menampilkan latar belakang yang menawan -ketchy.

Film Gertie The Dinosaurus bercerita tentang karakter dari Gertie yang merupakan seekor Brontosaurus yang terlihat bermain-main dalam rangkaian petualangan Gertie pada periode prasejarah. Suatu hal yang benar-benar baru dari pertunjukan film yang begitu hebat sehingga menggoda McCay untuk juga ikut muncul sesering mungkin secara langsung dengan film tersebut, seperti halnya pada saat ia menginstruksikan Gertie dalam melakukan berbagai trik ataupun ia berbicara kepada Gertie ketika karakter animasi tersebut melakukan

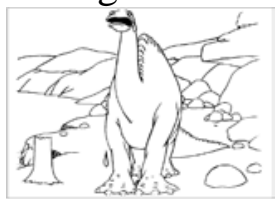

Gb 8 Gertie

Dinosaurus kesalahan. Tampak terlihat sebuah frame animasi yang diambil dari film animasi Gertie The Dinosaur di tahun 1914 yang dibuat oleh Winsor McCay, yang dianggap sebagai seorang pionir animasi awal (Gb 8). Pada tahun 1918, McCay pun menciptakan filmnya yang paling ambisius, The Realistic of the Lusitania, yakni sebuah dokumentasi berdasarkan Peristiwa yang dialami oleh Angkatan Laut ketika mendapatkan bencana (bencana

yang pada saat itu sangat terkenal). Namun, pada awal tahun 1920an, ia pun keluar dari bisnis kartun animasi dan kembali ke komik, meninggalkan lapangan yang sebenarnya potensi kesuksesannya masih begitu terbuka lebar.

\section{Animasi Boneka}

Pada tahun 1910, film animasi mengalami trobosan pada figure karakternya dengan sudah menggunakan boneka yang mungkin bisa dianggap boneka terbesar sepanjang masa yang digunakan oleh seorang animator. Ladislav Starevicz kelahiran Polandia, saat masih berada di Rusia dengan membuat beberapa fiksi pendek yang menghadirkan peristiwa dari suatu aksi hewan serangga. Gerakan-gerakan yang diperlihatkannya pada serangga tersebut, dianggap realistis sehingga membuat bingung para penontonnya dan mempertanyakan hal tersebut, bagaimana adegan itu bisa dibuat. Seperti animator lainnya, Starevicz memang orang yang memiliki kesabaran yang menakjubkan, dengan kawat yang senagaja diberikan pada sendi di serangga yang terbuat dari boneka plastik, Starevicz mampu memanipulasi aksi animasinya itu dengan mengubah sedikit demi sedikit posisi serangga untuk kemudian direkam secara frame by frame-nya. 
Film yang paling terkenal saat itu adalah The Revenge of a Cameraman Kinematograph. Dengan ceritanya yang lucu dan gerakan begitu terperinci dari boneka serangga, kenyataannya telah menghadirkan film yang benar-benar mengasyikan saat itu. Dimana karakter kumbang benar-benar seperti hidup, layaknya seorang manusia. Dalam adegan diperlihatkan bagaiman si Kumbang sedang melihat film bersama istrinya, yang tiba-

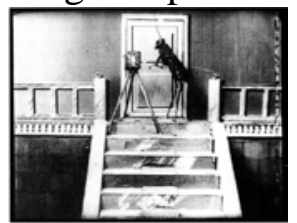

Gb 9 The Revenge of a Cameraman

Kinematograph tiba saja sang istri langsung marah. Lalu Belalang, memfilmkan kumbang yang sedang berhubungan intim yang telah menghinanya, seperti yang terlihat dalam gambar. Adegan tersebut merupakan peristiwa dalam film The Revenge of a Cameraman Kinematograph. Starevicz banyak membuat film animasi live-actionnya di Rusia, kemudian ia melarikan diri ke Paris setelah Revolusi Bolshevik di tahun 1917 dan untuk beberapa dekade lamanya ia tetap aktif membuat film.

Pada periode awal film animasi ini, meski teknik yang dibuat oleh para seniman begitu sederhana dan rumit, namun hal itu dianggap sangatlah menakjubkan. Bagaimana para animator tersebut begitu tekun dan telaten dengan membutuhkan kesabaran yang luar biasa dalam menghasilkan kreasinya secara individu ataupun bersama asistennya.

\section{Animasi Abstrak}

\section{A. Situasi Sebelum Animasi Abstrak}

Selama akhir abad ke-19 dan awal abad ke-20, seniman telah bergerak ke arah karyakarya yang gayanya menunjukkan sikap yang semakin tidak obyektif. Kadang-kadang hanya dari judulnya saja memungkinkan khalayak dapat mengetahui apa yang diwakili oleh bentukbentuk yang terbilang aneh dan tidak umum yang terdapat dalam sebuah karya. Pada tahun 1910, Abstract Watercolor karya Wassily Kandinsky telah membuat terobosan dengan menghadirkan lukisan yang isinya hanya berupa bentuk seadanya yang memiliki warna seperti begitu saja, bahkan sebenarnya lukisan tersebut tidak menggambarkan suatu apa pun.

Peristiwa tersebut membuat para seniman lainnya dengan cepat mengikutinya, sehingga dunia pun mulai mengenal bentuk abstrak dalam seni, untuk selanjutnya abstraksi gambar menjadi salah satu tren yang paling utama dalam seni modern. Gaya yang tidak representatif ini membutuhkan waktu untuk dapat berkembang menjadi sebuah film. Pada akhir tahun 1910-an di Jerman, beberapa seniman percaya bahwa film adalah seni visual seperti lukisan, bentuk yang paling murni untuk sebuah karya abstrak.

\section{B. Animasi Abstrak}

Film animasi abstrak paling awal rupanya dibuat di Jerman oleh Walter Ruttmann, meski sangatlah memungkinkan dalam hal ini dapat terbantahkan kelak melalui pandangan yang berbeda seperti alasan yang telah dijelaskan dalam pendahuluan sebelumnya tentang sejarah film dan animasi itu sendiri. Ruttmann juga pernah belajar melukis, dan bekerja dengan gaya abstrak dan ekspresionis. Namun, sejak awal, ia juga tertarik pada film. Pada 
tahun 1913, ia mengutuk upaya dari Autorenfilm ${ }^{1}$ yang dianggapnya sia-sia dalam menyuntikan kualitas ke dalam sinema. Sikap Ruttmann ini menyebar ke pembuat film eksperimental lainnya di tahun 1920-an. Pada tahun 1918, ia juga tertarik dengan gagasan lukisan bergerak dan dengan cara yang digunakannya, ia pun menciptakan hal tersebut ke dalam filmnya. Rupanya dengan mengetahui sedikit teknik animasi komersil, Ruttmann pun melukis dengan cat minyak di atas kaca, menghapus beberapa bagian dari cat yang basah dan segera menggantikannya. Lalu di potret dari atas pada setiap perubahannya dengan pencahayaan yang diposisikannya dari bawah kaca. Ia pun menghadirkan animasi Lichtspiel Opus 1 yang mengantarkan dirinya ke Frankfurt pada awal April 1921 dan mendapatkan gala perdananya di Berlin pada akhir bulan itu. Ruttmann pun segera melanjutkannya dengan membuat tiga film pendek yang serupa pada kesempatan berikutnya, yakni Lichtspiel Opus 2 (1921), Ruttmann Opus 3 (1924), dan Ruttmann Opus 4 (1925) -hal Ini sekarang lebih dikenal sebagai Opus 1, Opus 2, dan seterusnya. Masing-masing sebagai bentuk abstrak yang tampak terlihat seperti tumbuh, lalu menyusut, dan mentrans-mutasikan kedalam perubahan bentuknya dengan cara yang terlihat hidup. Ruttmann bermaksud agar film-filmnya ditampilkan dengan skoring musik yang orisinil bagaimana filmnya tersebut dilakukan dengan melalui pewarnaan tangan.

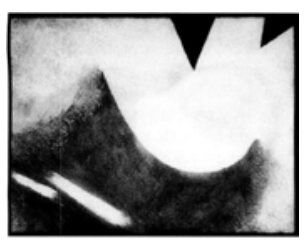

Gb 10 Opus 2

Dalam Opus 2, Ruttmann membuat gradasi pada tekstur yang halus dan disaat bentuk-bentuk abstrak itu dihadirkan secara bersamaan, satu sama lainnya secara ritmis berpadu dan kemudian berpisah. Konsep dari Ruttmann ini sekarang banyak diperlihatkan dalam instagram, facebook dan sebagainya sebagai upaya untuk menghasilkan karya senirupa tertentu. Memainkan penggabungan beberapa warna dari cat air, yang kemudian digerakan sekitar bingkai (frame), sehingga cat warna tersebut bergerak sesuai keinginan yang kemudian di rekam secara langsung oleh kamera.

Salah satu seniman film periode awal animasi abstrak ialah Hans Richter, yang pernah belajar seni dan bekerja dengan kelompok ekspresionis. Selama Perang Dunia I, Richter bertemu dengan sekelompok Dadais di Swiss, termasuk seorang seniman Swedia, Viking Eggeling, yang juga pernah tinggal di Jerman. Eggeling terpesona dengan gagasan menggunakan seni sebagai sarana universal komunikasi spiritual. Richter dan Eggeling pun kembali ke Jerman, dan masing-masing mengerjakan potongan-potongan kertas panjang gulungan yang berisi beberapa rangkaian gambar yang memiliki sedikit perbedaan bentuknya. Keduanya mencari cara untuk mengubahnya menjadi gambar bergerak yang akan menjadi semacam musik visual. Pasangan inipun diizinkan untuk menggunakan fasilitas Ufa, dari tahun 1910 hingga 1921, mereka bereksperimen dengan lebih menjiwai terhadap potongan-potongan dari bingkai pendek dari gulungan yang kemudian di foto. Richter mengklaim telah membuat film animasi abstrak pertama, yang diberi judul dengan Rhythm us 21, di tahun 1921, menariknya film tersebut tidak ditampilkan secara publik sampai bertahuntahun kemudian lamanya.

\footnotetext{
${ }^{1}$ Selama tahun 1913 muncul istilah Autorenfilm, atau "film penulis" di Jerman. Istilah penulis disini tidak berarti kemudian disamakan dengan apa artinya auteur -film sutradara- pada hari ini. Sebaliknya, Autorenfilm dipublikasikan karena sebagian besar didasarkan pada seorang penulis terkenal yang telah menuliskan naskah atau karya sastra aslinya yang kemudian diadaptasikan ke film. Sedangkan untuk sutradara filmnya itu sendiri jarang disebutkan. Autorenfilm, pada dasarnya setara dengan istilah Film d'Art di Perancis, sebagai upaya lain di Jerman dalam menciptakan sinema artistik. Demikian pula halnya terhadap bintang panggung yang dipekerjakan dengan ditampilkan lebih menonjol dalam publisitas untuk film-film semacam itu. Beberapa sutradara teater terkemuka, terutama Max Reinhardt, juga ikut bekerja di sinema meskipun hanya sebentar (Bordwell 3:57).
} 
Eggeling, rekan dari Richter, bertemu dengan Erna Niemeyer seorang animator berpengalaman, dan dia pun menekuni gambar gulungannya dan memotretnya untuk membuat Diagonalsymphonie (Diagonal Symphony). Eggeling melihat gambar-gambar

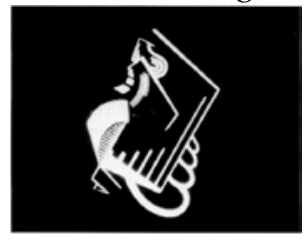

Gb 10 Diagonal Symphony abstraknya yang bergerak sepadan dengan musik, lalu membiarkan film pendeknya tersebut ditampilkan tanpa iringan suara. Tampilan rangkaian yang bervariasi pada parallel garis diagonal putih yang bergerak dengan pola yang kompleks dengan latar belakang hitam. Dalam Diagonal Symphony, bentuk lengkungan berputar disekitar motif diagonal yang menjadi dasar untuk mengatur pola abstrak sepanjang film. Untuk pertama kalinya animasi Symphony Diagonal ini ditampilkan di akhir

tahun 1924, terjadi di akhir tahun 1924, setahun sebelum Eggeling meninggal.

\section{Seni Komersil}

Teknik yang terjadi pada animasi abstrak juga ikut mempengaruhi sinema komersil, terutama dalam karya pembuat film yang dikenal sangat khas, yakni Lotte Reiniger. Terlatih sebagai seniman selama tahun 1910-an, ia dianggap sangat terampil dalam cutting out siluetnya yang sangat halus atau yang rumit sekalipun. Selama awal tahun 1920-an, ia menciptakan rangkaian efek khusus dalam iklan yang dibuatnya. Dari tahun 1923 hingga 1926, ia mengerjakan filmnya yang paling penting, The Adventures of Prince Achmed, yang dibantu oleh Ruttmann dan yang lainnya. The Adventures of Prince Achmed sendiri adalah film animasi panjang pertama (sebelum munculnya Snow White and the Seven Dwarfs-nya Disney). Prince Achmed menceritakan sebuah dongeng Arabian Nights melalui sosok-sosok siluet yang difotonya serta menciptakan latar belakang yang teduh yang terlihat dengan begitu halus. Sehingga animasi yang berjudul The Adventures of Prince Achmed ini pun memperlihatkan bagaiman nuansa yang dimilikinya tampak kelabu guna memperlihatkan kedalaman gambar pada latar belakangnya, sedangkan sosok yang bergerak terdiri dari boneka yang dapat digerakkan dalam gambar siluet. Reiniger pun kemudian diketahui telah membuat film fantasi siluet seperti itu selama beberapa dekade di beberapa negara.

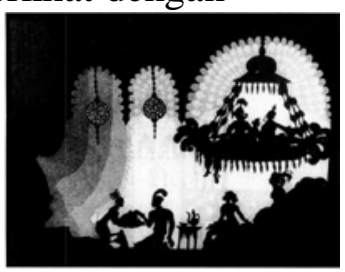

Gb 11

\section{Eksperimen Baru}

\section{Musik Visual}

Animasi abstrak sebenarnya bertahan hingga di tahun 1930-an. Oskar Fischinger, di Jerman, berusaha untuk menghubungkan bentuk gerakan dengan musik. Ia sangat mendukung perusahaan kecil yang fokusnya terutama dalam pelayanan iklan, sehingga Fischinger dapat mengeksplorasi kemungkinan-kemungkinan dari warna-warna dalam animasi abstrak. Misalnya yang terlihat dalam filmnya yang berjudul Circles (1933). Merupakan film berwarna pertama yang dibuat di Eropa, dengan memiliki durasi sekitar tiga menit, ia pun mencoba menyampaikan pesan singkat Toliras reaches all [social] circles. Circles menjadikan pusat film ini terdiri dari pola lingkaran yang kompleks yang berputar dan sangat bergantung dengan musik yang mengiringinya. Tahun 1935, dan Fischinger 


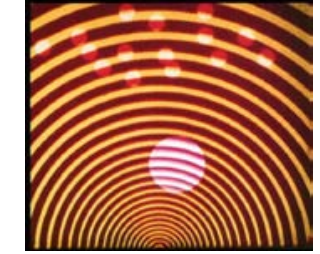

Gb 12 Circles

membuat iklan rokok dan pasta gigi sambil menyelesaikan komposisi yang ada didalam warna biru, di mana objek tiga dimensi berongga berada di ruang biru yang abstrak. Tahun 1935, Fischinger membuat iklan rokok dan pasta gigi sambil menyelesaikan komposisi yang ada di dalam warna biru, di mana objek tiga dimensi berongga berada di ruang biru yang abstrak.

Fischinger menyadari bahwa dia tidak bisa menetap dengan Nazi untuk tinggal di Jerman sehingga memutuskan pindah ke Los Angeles. Disana ia pun mampu membuat beberapa film animasi, termasuk satu film pendek yang diproduksi oleh MGM, yaitu An Optical Poem (1937). Dengan cepat, film tersebut diterima dengan cukup baik karena dianggap sebagai hal yang baru, tetapi sebaliknya divisi animasi di MGM malah tidak bersimpati dengan pendekatan Fischinger tersebut. Segera saja ia bekerja di studio Disney, meski hanya sebentar dilakukannya, dan saat di studio tersebut, melalui beberapa sentuhannya ia pun terlibat dalam disain film Fantasia dan Pinocchio yang seringkali dikaitkan dengan dirinya. Tapi yang jelas sebagian besar pekerjaannya di Amerika dijalankan dengan dukungan yang sedikit. Meski demikian, film pentingnya justru lahir setelah dirinya pindah ke Amerika, Motion Painting No. 1 (1947), yang di danai oleh Yayasan Guggenheim, yaitu berupa satu shot panjang, yang berlangsung kira-kira sepuluh menit, melalui teknik film frame by frame-nya, Fischinger menghadirkan sapuan kuas yang ditorehkan ke dalam lukisan untuk menciptakan lukisan yang aneh, yang dibangun dengan komposisi yang kemudian disusul dengan komposisi yang lain yang ada diatasnya. Enam lapis akrilik yang diletakkan ditumpuk untuk mencapai efek yang dibuat Fischinger di kameranya selama berbulan-bulan hanya untuk memperlihatkan apakah tekniknya berhasil atau tidak. Hasilnya kemudian diatur dan disesuaikan dengan Brandenburg Concertos-nya Johan Sebastian Bach, melalui latihan guna memanjangkan garis pada warnanya. Setelah akhir tahun 1940-an, Fischinger tidak dapat menemukan dukungan finansial, dan ia pun beralih untuk kembali menjadi pelukis abstrak.

\section{Awal Perkembangan Eksperimen Baru}

Pada tanggal 3 Mei 1925, sebuah pertunjukan yang sangat penting dipentaskan dimana ditayangkan beberapa film-film abstrak di teater Ufa di Berlin. Termasuk Diagonal Symphony, lalu ketiga film pendek milik Ruttmann yakni Opus, dan seri Rhythmus-nya Richter. Dalam program pertunjukan tersebut juga menghadirkan dua film Prancis dari Rene Clair yang berjudul Entr'acte dan karya Dudley Murphy bersama Fernand Leger yakni Ballet Mecanique. Pembuat film Jerman pun mengakuinya sebagai dorongan gelombang eksperimental baru. Dengan menggunakan boneka yang telah di disain oleh Leger, Ballet Mecanique yang diketahui sebagai bentuk penghargaan mereka kepada Charlie Chaplin. Karya dari Murphy dan Leger ini, nantinya dikenal sebagai sinema pur dalam sejarah film dunia.

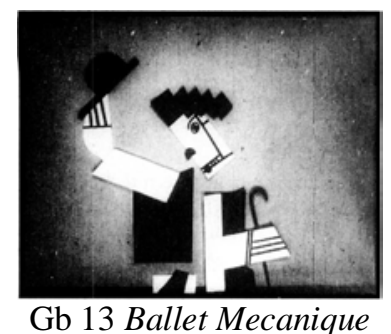

Beberapa tahun kemudian, film model eksperimen baru dari Ballet Mecanique tersebut, muncul kembali secara tak terduga pada tahun 1929. London Film Society menyediakan dana untuk sebuah film pendek bagi seorang pemuda Selandia Baru, yang merupakan seorang pelukis dan penulis yaitu Len Lye, seorang eksperimental film lainnya yang sudah mulai bekerja selama era film bisu. Gambar-gambarnya sudah ditempatkannya sendiri oleh Lye mulai sejak tahun 1927 hingga 1929, yang ternyata sangat mendukungnya 
ketika karyanya tersebut menjadi tirai pembuka di sebuah teater, yang ditayangkan perdana di Masyarakat Film pada tahun 1929, meskipun karyanya itu telah membingungkan sebagian

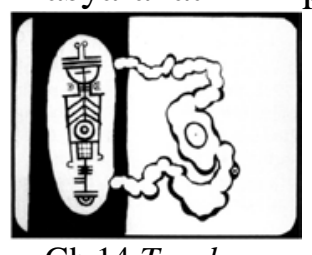

Gb 14 Tusalava besar penontonnya melalui imaj esoteriknya. Dasar dari figur yang abstrak yang dibuat oleh Len Lye dalam filmnya, Tusalava merupakan sebuah seni dari suku Aborigin di Australia. Kemudian setelah menciptakan Tusalava di tahun 1929, Lye pun mencoba membuat film serupa yang mengakibatkan dirinya tidak kurang mendapatkan dukungan. Dimana dia pun mulai melukis langsung di filmnya.

Seperti halnya Fischinger, ia pun melakukan eksplorasi berbagai kemungkinan dari proses warna baru yang tersedia pada pertengahan tahun 1930-an. Colour Box (1935) adalah bentuk animasi patah-patah untuk musik dansa. Sebuah film yang sangat populer dan mempengaruhi para animator Disney di film Fantasia. Dalam Rainbow Dance (1936), Lye mengambil gambar live-action yang pada awalnya merupakan bahan baku dari stok film hitam-putih yang kemudian ia manipulasikan di lapisan emulsinya sebagai stok film warna guna menghasilkan rona padat yang luar biasa. Satu-satunya referensi film yang ia tunjukan ke kantor pos, agar mendapatkan dukungan keuangannya, yang pada akhirnya film itupun memiliki slogan A Post Office Savings Bank puts a pot of gold at the end of the rainbow for you. Lalu di akhir tahun 1930-an, ketika sponsor mulai menurun bahkan ia tidak mendapatkan dukungan, akhirnya divisi Film GPO, Grierson pun membantu Lye dengan membiayai proyeknya ataupun mencari pendukung finansial untuknya. Lye mulai mengarahkan film dokumenter untuk divisi Film di GPO, dan berhasil membuat When Pie Was Opened (1941), sebuah film pendek sederhana tentang membuat makanan yang enak. Terlepas dari masalah kehadiran film pertamanya itu, Lye kemudian menjadi salah satu animator abstrak terpenting pada era suara.

Beberapa film eksperimental yang paling signifikan muncul di tahun 1930-an dan kenyataannya banyak menggunakan teknik animasi. Ini dikarenakan film animasi membutuhkan anggaran yang relatif sedikit untuk set, aktor, dan kebutuhan lainnya daripada film fiksi live-action. Bermodalkan kamera dan sedikit kesabaran serta beberapa bahan sederhana, seorang pembuat film secara personal ataupun kelompok kecil dapat menciptakan karya yang kaya imajinatif. Selain itu, gaya animasi cocok untuk digunakan dalam pembuatan film iklan, sehingga beberapa seniman dapat menghidupi diri mereka sendiri dengan membuat iklan atau kebanyakan juga untuk proyek-proyek pribadi. Sebagian besar animator Eropa terus menghindari pembuatan animasi dengan teknik jaringan yang dianggap sebagai nilai-nilai tradisional, kemungkinannya karena mereka mengaitkannya dengan pandangan komersialisme ala Hollywood. Sebagai gantinya, mereka pun mulai merancang metode alternatif yang lebih cerdik untuk menciptakan gerakan frame by frame.

Salah satu individu yang paling memiliki dedikasi dalam periode ini adalah Berthold Bartosch, yakni seorang seniman Ceko yang telah membuat film pendidikan animasi di Wina dan Berlin selama bertahun-tahun setelah Perang Dunia I. Dia juga ikut membantu Lotte Reiniger di film The Adventures of Prince Achmed, film di syut dari lapisan bahan yang tembus cahaya untuk menghasilkan daratan, langit, dan efek laut (lihat gambar film The Adventures of Prince Achmed). Pada tahun 1930, penerbit Kurt Wolff (yang menemukan Franz Kafka di tahun 1920-an) menugaskan Bartosch untuk membuat film berdasarkan buku sosialis dari potongan kayu oleh Frans Masereel. Bartosch pun kemudian mendirikan stan animasi di bioskop seni di Paris, tepatnya di Theatre du Vieux Colombier. Dengan 
menggunakan kaca berwarna hitam, sabun, dan bahan-bahan lainnya, selama dua tahun ia menciptakan The Idea (1932). Film Alegori yang diangkat dari konsepsi para pekerja, yang dipersonifikasikan sebagai wanita telanjang, dengan diperlihatkannya seorang tokoh yang sedang menyampaikan idenya kepada rekan-rekan kerjanya yang telah ditekan oleh tirani perusahaan. Meskipun ditampilkan dalam bentuk sosok manusia yang sederhana, dengan potongan yang kaku, mereka pun terlihat dapat bergerak di dalam atmosfer kota yang teduh dengan begitu lembut. Meskipun Bartosch telah membuat beberapa iklan selama beberapa dekade berikutnya, ia tidak pernah menyelesaikan film besar lainnya.

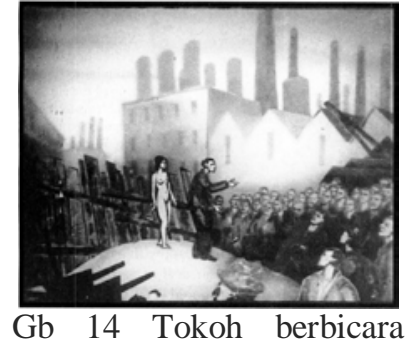
tentang idenya kepada para pekerja pabrik. Film dengan teknik pengambilan dari atas meja transparan dengan cahaya dari bawah.

Film Bartosch ternyata menginspirasi dua animator penting yang masuk sebagai pembuat film. Alexandre Alexeieff kelahiran Rusia yang telah menjadi desainer panggung dan juga ilustrator buku di Paris. Setelah ia melihat pertunjukan The Idea, ia pun mencoba menciptakan efek ukiran pada film. Sekitar tahun 1934, Alexeieff dan mitranya dari Amerika Claire Parker (yang akhirnya mereka pun menikah di tahun 1941) menemukan teknik animasi yang mereka sebut dengan pinboard. Berupa frame yang terdiri dari kain yang diregangkan dimana ditanam setengah juta pin yang berlipat ganda. Dengan mendorong pin di berbagai area papan ke berbagai ketinggian dan meneranginya dari samping, Alexeieff dan Parker dapat membuat gambar dalam nuansa yang kelabu. Lalu memindahkan beberapa pin di antara setiap frame dan menghasilkan gambar dengan tekstur sedemikian rupa sehingga tidak ada jenis animasi lain yang bisa menduplikasikannya. Lalu mereka dengan cepat menghasilkan sebuah mahakarya, yang diberi judul Night on Bald Mountain di tahun 1934, yang penuturannya diatur seperti warna puisinya Walpurgisnacht karya Mussorgsky di film. Sesuai dengan inti pembahasan dari karya Mussorgsky, Alexeleff dan Parker menganimasikan rangkaian gambar mutasi yang aneh (Gb 15) bagaimana visual dapat terbang mendekat dan menjauh dari kamera dengan kecepatan yang memusingkan. Film ini di terima dengan baik oleh para kritikus dan penonton film, tetapi pasangan ini harus menerima kenyataan hidup mereka dan beralih ke film iklan untuk mencari nafkah agar dapat membiayai hidup mereka. Film-film pendek ini, dibuat dengan menganimasikan objek satu frame untuk satu waktu, yang saat ini dianggap klasik. Alexeleff dan Parker membuat satu film pinboard yang lainnya lagi selama periode ini, sebuah karya yang menawan dengan berdurasi sekitar dua menit berjudul En Passant (In Passing di tahun 1943), untuk mengilustrasikan lagu rakyat dari Prancis-Kanada, yang diproduksi oleh Dewan Film Nasional Kanada, setelah keduanya melarikan diri saat perang di Perancis dan kemudian tinggal dan menetap di Amerika Serikat.

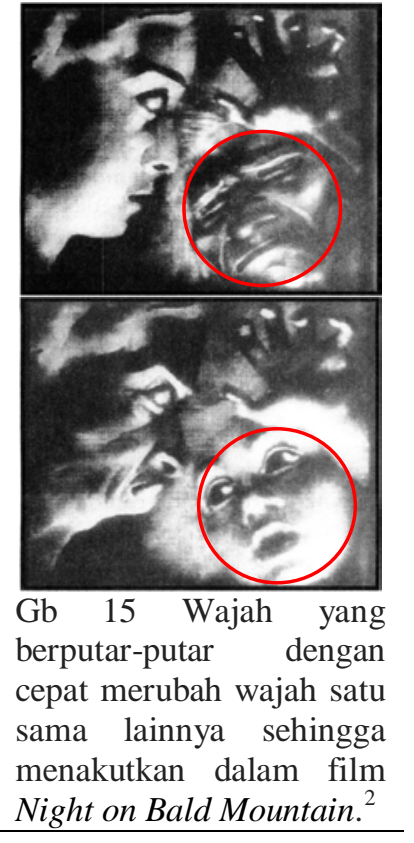

\section{Eksperimen Baru di Amerika Serikat}

Pelukis Mary Ellen Bute mulai membuat film animasi abstrak di tahun 1930-an. Seperti Fischinger, ia menggunakan potongan-potongan musik yang akrab dengan publik lalu

\footnotetext{
2 Bordwell, David and Kristin Thompson. Film History, 14:320; McGraw-Hill Companies, Inc-New York, 2008.
} 
menciptakan suatu bentuk yang bergerak-gerak untuk di sinkronkan dengan mengikuti perubahan nada dari musik. Film-film pertamanya, seperti Synchrony No.2 (1935) dan

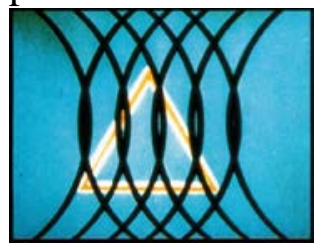

Gb 16 Film Escape

Parabola (1937) adalah film yang berwarna hitam dan putih, tetapi di Escape (1937), ia memperkenalkan film berwarna sebagai seorang pengusaha yang pandai. Bute berhasil mendistribusikan film-filmnya langsung ke bioskop komersil yang umumnya menayangkan kartun sebelum feature film ditayangkan. Dia pun tetap terus membuat film pendek meski hanya sekali-sekali sampai pada tahun 1960-an.

Sedangkan di tempat yang berbeda, beberapa pembuat film di Pantai Barat bekerja untuk membuat animasi abstrak. Five Film Exercises karya John dan James Whitney (selesai di tahun 1944) menggunakan trek suara yang terdiri dari musik yang disintesiskan, jauh sebelum munculnya musik elektronik. Sedangkan pelukis model Harry Smith malah mengeksplorasi teknik membatik, dengan menerapkan lapisan cat pada strip film 35mm, ia mengarahkan polanya dengan menggunakan pita atau lilin. Dalam beberapa abstraksi awal, tampak Smith memperlihatkan sketsa dari tekstur yang dominan mengisi bentuk yang terus berubah-ubah, sementara itu bintik-bintik warna menutupi disainnya.

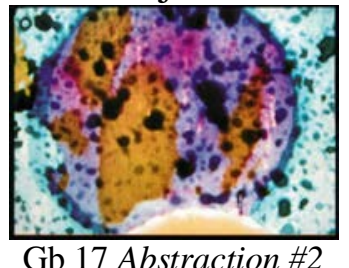

Gb 17 Abstraction \#2 (1939-1946)

Sementara seniman yang lain mengeksplorasi gambar sebagai sumber-sumber animasinya, animator boneka terkemuka di dunia, Ladislav Starevicz, yang telah memulainya saat di Rusia, yang kemudian beremigrasi ke Paris setelah Revolusi Rusia, melanjutkan gaya animasinya yang terbilang unik tersebut. Salah satu karya terpanjangnya pun lahir dengan judul The Mascot (1934), memperlihatkan live-action dengan boneka yang mengisahkan penjahit yang miskin pembuat boneka mainan untuk merawat putrinya yang sedang sakit. Benda-benda disekitarnya seperti anjing mainannya dapat berubah menjadi hidup sebagai protagonis, dan berangkat mencari jeruk untuk anaknya yang sedang sakit itu. Selama petualangannya sang anjing bertemu dengan berbagai tokoh aneh di sebuah penginapan. Nampak dalam gambar animasi kerangka burung dan seekor ikan

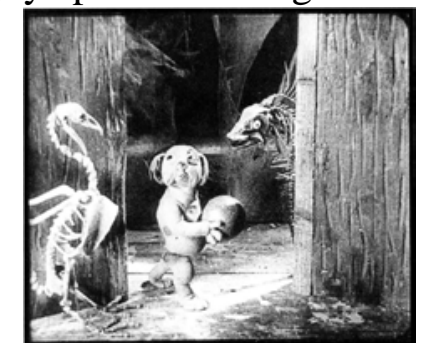

Gb 18 The Mascot yang berusaha keras menggangu sang protagonis dalam The Mascot. Adegan ini dianggap sebagai film yang menampilkan keahlian Starevicz dalam menghadirkan banyak karakter dan sekaligus juga memberi mereka wajah yang ekspresif dan mobile. Starevicz terus membuat film animasi meski hanya sekali-sekali saja di Paris hingga kematiannya pada tahun 1965.

\section{Animasi di Amerika Serikat}

Gejolak ekonomi dan politik dari tahun 1930 hingga 1945 telah membantu mendorong produksi film dokumenter, terutama yang dibuat oleh pembuat film 'kiri' ideologi. Setelah Perang Dunia II berakhir, perang dingin telah menciptakan atmosfir yang kurang reseptif untuk film-film semacam itu, karena kaum 'kiri' yang seringkali menghadapi perjuangan berat dengan diberlakukannya sensor terhadap film secara langsung. Sedangkan selama tahun 1930-an dan awal tahun 1940-an, pembuat film eksperimental sering bekerja secara sembunyi-sembunyi atau seperti terisolasi karena sedikitnya dukungan finansial kepada mereka. Namun, situasi mereka tersebut agak membaik, setelah tahun 1945, munculnya beberapa bioskop yang di khususkan untuk pemutaran film seni, telah tersebar di 
beberapa wilayah, selain juga diikuti dengan tumbuhnya beberapa festival film internasional, dan dukungan baru dalam bentuk hibah untuk para pembuatan film.

\section{A. Rampingnya Animasi Amerika Serikat}

Dengan cara yang sama seperti tenaga kerja yang terlibat dalam pembuatan film liveaction yang terbagi-bagi dalam beberapa bagian divisi dan bidang pekerjaan, maka para pembuatan film animasi juga tidak luput untuk dijadikan standar industri di Amerika. Beberapa pembuat film menyadari bahwa kartun dapat dibuat lebih ekonomis dan lebih cepat jika karya itu dapat dipecah menjadi beberapa bagian pekerjaan pada sistem jalur perakitannya. Animator dapat merancang temanya sekaligus juga mengawasi pekerjaan yang lain, sedangkan beberapa pekerja tambahan bekerja untuk membuat kebutuhan gambar yang sebagian besar diperlukan untuk menciptakan gerakan film animasi. Selain itu, selama tahun 1910-an, muncul inovasi teknis sebagai upaya dalam mempercepat proses animasi, seperti: pencetakan untuk mengatur latar belakang secara mekanik, penggunaan sel yang transparan, dan teknik slash untuk aksi pada gambar.

Animator awal seperti Emile Cohl dan Winsor Mccay telah diketahui bahwa mereka bekerja dengan membuat banyak sekali gambar. Sebelumnya telah dijelaskan bagaimana McCay telah bekerja dengan membuat ribuan gambar untuk menghasilkan karya filmnya. Tapi McCay mengatasinya dengan memiliki asisten untuk mengamati dan melacak latar belakang yang tidak bergerak diatas selembar kertas. Pada tahun 1913, John Randolph Bray merancang metode mekanisasi proses animasi: ia mencetak begitu banyaknya latar belakang

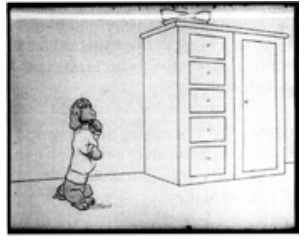

Gb 19 yang sama pada setiap lembar kertas, kemudian melukiskan bentuk animasi di atas latar belakang itu untuk menciptakan film The Artist's Dream. Pada Gb 19, merupakan hasil dari Bray dalam film animasinya yang berjudul The Artist's Dream (1913), ia melukis latar belakang di dalam filmnya yang di cetak pada beberapa lembar kertas. Sedangkan di bulan Desember 1914, Bray memulai pekerjaannya di studionya sendiri,

dan mempekerjakan seorang pemuda bernama Earl Hurd. Pada bulan yang sama, Hurd mengajukan hak paten untuk idenya atas apa yang telah ia lakukan, dimana ia menggambar tokoh yang bergerak untuk kartun animasinya di atas lembaran transparan yang terbuat dari seluloid (lembarannya disebut eel, menimbulkan istilah eel animated -animasi belut). Teknik ini berarti disetiap bagian yang bergerak dapat digambar ulang sedikit demi sedikit pada sel yang terpisah sementara latar belakangnya tetap dibuat secara konstan. Serial dari Hurd yang berjudul Bobby Bumps adalah salah satu kartun paling populer dalam dekade ini (gambar disamping). Tampak terlihat animasi Bobby Bumps and His Goatmobile (1917), dimana gambar bergerak menggunakan lembaran seluloid transparan yang ditempatkan diatas sebuah lukisan yang diatur sedemikian rupa.

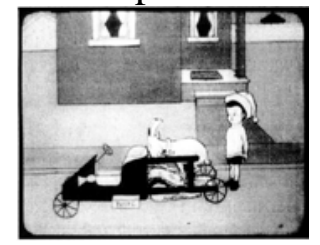

Gb 20

Dalam periode yang sama, Raoul Barre mengembangkan sistem slash animated. Sebuah gambar yang nantinya akan digambar di atas kertas, dan kemudian bagian tubuhnya yang bergerak akan dipotong dan digambar ulang di atas kertas di bawah bagian gambar yang tersisa, yang tidak di potong. Untuk menjaga agar bentuk tetap stabil di layar ketika bagian yang bergerak digambar ulang, Barre menyarankan untuk menstabilkan lembaran kertas tersebut pada sepasang pasak di bagian atas gambar. Sistem pasak ini ternyata tetap menjadi pusat animasi yang digunakan sejak saat itu, karena memungkinkan setiap sel yang berbeda yang digerakkan oleh animator dapat disatukan dengan lancar. Selama tahun 1915, Barre pun 
tetap menggunakan sistem slash ini untuk membuat rangkaian singkat dari Animated Grouch Chasers bagi Perusahaan Edison. Ternyata hal ini merupakan live-action pendek yang

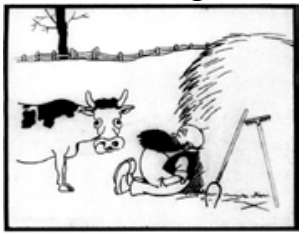

Gb 21 ditanamkan melalui sekuens animasi. Pada gamar 21, terlihat sebuah kartun tahun 1915 dari perusahaan milik Thomas Alva Edison yang berjudul Cartoons in the Hotel, sebuah animasi dari Barre yang menggunakan sistem slash. Gambar tubuh sapi dibiarkan statis tanpa kepala, sehingga gambar kepal yang terpisah, memungkinkan untuk dapat bergerak.

Selama tahun 1910-an, animasi dilakukan oleh perusahaan independen yang menjual hak atas film mereka kepada distributor. Dalam program yang telah dirancang, kadangkadang film kartun dipertunjukan secara singkat sebelum ditayangkannya film panjang. Selama tahun 1920-an, kerja animasi sebagian besar berkat adanya perangkat yang dapat menghemat tenaga kerja yang telah dikembangkan selama tahun 1910-an, sehingga film pendek animasi menjadi elemen yang lebih teratur dari program film.

\section{B. Produksi Animasi Menjadi Bagian dari Program Produksi Film}

Teknik dasar film animasi telah ditemukan selama tahun 1910-an, dan periode pascaPerang Dunia I telah menyaksikan booming-nya animasi. Studio baru animasi yang independen pun mulai bermunculan, menciptakan output yang lebih besar dan menerapkan beberapa pembagian kerja didalamnya, yang menyebabkan proses animasi menjadi jauh lebih efisien. Biasanya, chief animator meletakan model dasar untuk adegan, inbetweeners mengisinya dengan gambar tambahan untuk sebuah gerakan, pekerja lain menelusuri gambar ke dalam jaringan, yang lainnya mengisi gambar dengan cat, dan seorang sinematografer memotret gambar frame by frame. Hasilnya merupakan rangkaian kartun dalam satu buah judul dapat di rilis setiap satu bulan bahkan dua mingguan. Generasi animator yang sama sekali baru juga mulai mendirikan toko sebagai informasi teknis tentang jaringan dan sistem slash untuk disebar-luaskan. Sebagian besar perusahaan animasi menghasilkan serial dengan karakter atau tema yang berkelanjutan -serial. Film-film ini akan di rilis melalui distributor independen, tetapi distributor itu mungkin menanda-tangani kontrak dengan salah satu perusahaan besar Hollywood dimana pada perusahaan Hollywood tersebut, kartun ditempatkan pada program tersendiri. Distributor independen paling sukses dalam era ini adalah Margaret J. Winkler Mintz. Kemudian pada awal tahun 1920-an, Mintz pun membiayai dan merilis tiga serial yang paling populer pada decade itu, yakni: film Out of the Inkwell karya Fleischer Brothers, kartun yang didasarkan pada komik Fisher yakni Mutt and Jeff yang sangat dicintai oleh Bud Fisher sendiri, dan beberapa upaya paling awal dari seorang Walt Disney.

Saudara-saudara Fleischer, Max dan Dave, telah bereksperimen dengan teknik film baru yang disebut rotoscoping pada pertengahan tahun 1910an. Rotoscope memungkinkan pembuatan film untuk mengambil film live-action, memproyeksikan setiap frame-nya ke selembar kertas, dan menelusuri garis besar gambar-gambarnya. Sebenarnya pada awalnya, alat tersebut ditujukan untuk keperluan pihak militer. Meskipun rotoscope dipatenkan pada tahun 1915, keadaan Perang Dunia I telah menunda pekerjaan mereka selanjutnya. Baru kemudian setelah perang, Max dan Dave pun kembali bekerja, kali ini mereka menelusuri gambar live-action sebagai tokoh kartun. Dengan menggunakan prolog live-action untuk setiap film dalam serial mereka, maka mereka menghadirkan penampilan Max Fleischer sebagai kartunis yang diwujudkan dalam tokoh Koko yang diciptakannya, yakni seorang 
badut yang muncul dengan keluar dari ruangan bertinta. Kartun pertama pun di rilis pada akhir tahun 1919, dan disusul dengan beberapa karya lainnya secara sporadis hingga tahun 1920. Anehnya Rotoscoping sendiri tidaklah dimaksudkan untuk meningkatkan efisiensi, seperti penemuan-penemuan sebelumnya dalam pembuatan kartun. Melainkan suatu penelusuran terhadap aksi dalam setiap satu gambarnya pada satu waktu dalam jaringan, karena dengan hal seperti itu kartunis dapat dengan mudah menghasilkan karakter yang bergerak secara alamiah sebagai sosok figur, tidak terlihat kaku, hanya menggerakkan satu atau beberapa bagian tubuh mereka, seperti pada slash ataupun sistem sederhana jaringan lainnya. Seperti aksi yang terjadi pada Karakter baru dari Fleischer, Koko the Clown, yang dapat mengayunkan anggota tubuhnya ke luar angkasa dengan bebas, dan pakaiannya yang longgar yang dapat berputar-putar disekelilingnya saat ia pergi. Tampak pada gambar, film Clown's Little Brother (1919-1920), memperlihatkan figur Koko yang melintas pada frame yang digerakan dengan teknik rotoscoped dengan terlihat begitu mudah dan lebih hidup sebagai

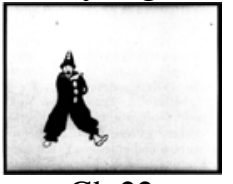
Gb 22 animasi tahun 1910-an. Fleischer kemudian juga menggunakan teknik standar jaringan, slashing, dan retacing, tetapi perangkat rotoscoping ini memberikan sebuah kebebasan baru. Terbukti pada serial Out of the Inkwell pun dapat berjaya selama tahun 1920an. Namun, di era awal bersuara, Fleischer pun menggantikan karakter Koko dengan Betty Boop dan Popeye yang sama-sama terkenal dan populer.

Serial Mutt and Jeff sebenarnya telah dimulai sebagai komik strip pada tahun 1911. Bintang-bintang yang dimunculkannya adalah dua orang yang berkumis, dengan ciri yang melekat pada mereka sangatlah spesifik, yakni yang satu tinggi dan yang satunya lagi pendek. Namun baru pada tahun 1916 seniman komik strip, Bud Fisher, sepakat untuk memberikan ijin komik stripnya tersebut diangkat kedalam bentuk animasi. Namanya pun selalu ditempatkan sebagai pencipta serial kartun, meskipun selama bertahun-tahun Raoul Barre, Charles Bowers, dan berbagai veteran animasi lainnya benar-benar menggambar kartunnya

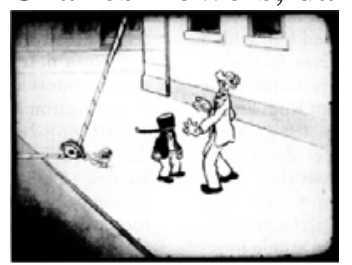

Gb 23 itu. Distributor Mintz mengontraknya untuk sebuah serial yang dirilis melalui Fox, dan tetap populer hingga tahun 1920an. Pada gambar memperlihatkan bagaimana Mutt berusaha membantu Jeff mengeluarkan panci yang melekat di kepalanya, yang mengakibatkan Jeff pusing sambil mengucapkan “dimana aku?” Padahal lokasinya terlihat di dekat sebuah gedung yang baru dibangun (1925).

Walt Disney muda dan temannya Ub Iwerks mendirikan firma seni pertama mereka sendiri yang komersial di Kansas City pada tahun 1919. Karena gagal menghasilkan uang, mereka pun kemudian bekerja untuk sebuah biro iklan dan membuat film-film animasi sederhana. Lalu mereka memulainya dengan Newman's Laugh-o-gram, yakni rangkaian film animasi pendek untuk distribusi lokal. Namun usaha mereka inipun juga mengalami kegagalan, lalu Disney pun pindah ke Hollywood. Pada tahun 1923, ia menerima dukungan dari Mintz untuk menciptakan rangkaian komedi Alice, yang belakangan menjadi bukti kesuksesan pertamanya. Bersama saudaranya Roy, ia pun kemudian membentuk Disney Brothers Studios, yang pada akhirnya tumbuh menjadi salah satu konglomerat hiburan terbesar di dunia. Selama tahun 1920-an, staf perusahaan termasuk beberapa animator utama, yang nantinya membuat serial untuk Warner Bros dan MGM pada tahun 1930-an, seperti: Hugh Harman, Rudolf Ising, dan Isadore "Friz" Freleng. Mereka semua bekerja pada serial 
Alice, yang menggabungkan live-action dengan teknik gambar kartun yang terbukti bukanlah hal baru dalam dunia kartun. Tampak dalam gambar kartun yang berjudul Alice in the Wooly West (1926), memperlihatkan tanda seru untuk mengekspresikan keheranan sang tokoh saat berhadapan dengan karakter tokoh dari dunia kartun serial lainnya. Pada tahun 1927, studio Disney pun beralih ke serial animasi sepenuhnya dengan menghadirkan Oswald the Rabbit. Namun, dalam

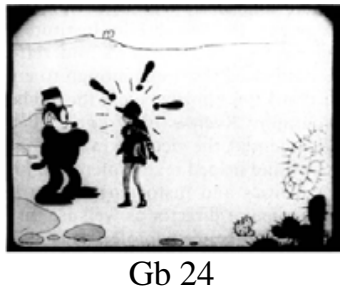
perlawanannya dengan hukum, Charles Mintz, suami dari distributor Disney, telah mengambil alih kendali atas karakter tersebut. Walt pun mencoba untuk mencari solusinya dengan menciptakan karakter baru yang disebut Mickey Mouse. Dua kartun Mickey pertama mengalami kegagalan dalam menemukan distributor. Tapi untuk usaha animasinya yang ketiga yang diberi judul Steamboat Willie, mendapatkan kesuksesan yang besar dengan menggabungkan teknologi suara terbaru. Hal itu membantu melemparkan Disney kedalam bisnis animasi pada tahun 1930-an.

Pelaku serial kartun yang lainnya dalam periode ini yang terbukti juga sangat populer ialah Paul Terry, yang telah bekerja di berbagai studio animasi selama tahun 1910-an, dan mulai mendirikan perusahaannya sendiri yakni Fables Pictures Inc. pada tahun 1921. Dia meluncurkan serial yang disebut dengan Aesop's Fables. Untuk menceritakan kembali dongeng klasik secara modern Terry pun menggunakan divisi perakitan lini kerja virtual dalam menghasilkan satu film per-minggunya; hasilnya pun terbilang lucu tetapi masih dianggap sebagai bentuk konvensional yang biasa.

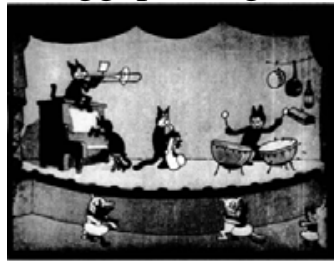

Gb 25

Dalam gambar Nightclub tempat protagonis menghabiskan gajinya dalam animasi The Spendthrift (1922), borosnya sang tokoh telah menyalahkan semua orang kecuali dirinya sendiri. Terry pun kemudian meninggalkan perusahaannya pada tahun 1928 untuk menciptakan Terrytoons, sebuah perusahaan yang ia jalankan hingga tahun 1955, karena ia menjual perusahaannya tersebut kepada produser televisi.

Sedangkan serial yang paling populer di tahun 1920-an yang dibintangi oleh Felix the Cat diciptakan oleh Pat Sullivan, yang telah membuka studionya sendiri sejak tahun 1915. Pada awalnya Sullivan membuka studionya hanya untuk membuat iklan dan film animasi. Tapi kemudian ia mulai membuat kartun Felix untuk studio Paramount sekitar tahun 1918. Meskipun Sullivan yang menanda-tangani semua filmnya, namun untuk chief animasinya sebenarnya adalah Otto Messmer, sehingga karakter Felix pun sebenarnya berasal dari Messmer yang sekaligus juga sebagai orang yang menangani proses animasinya tersebut. Mintz kemudian menanda-tangani pendistribusian serialnya di tahun 1922. Terbukti film itupun meraih kesuksesan, karena sebagian didapatkannya melalui daya tarik sang tokoh utamanya yang berupa seekor kucing, disamping juga atas gaya animasinya yang fleksibel. Dalam film-film ini, ekor Felix bisa terbang dari tubuhnya karena bisa membentuk sebuah simbol tanda tanya, yang juga digunakan sebagai tongkat untuk bersandar. Seperti pada gambar, tokoh Felix dengan sopannya memberi tip dalam Felix si Kucing di Futuritzy (1928). Pada pertengahan tahun 1920-an, film-film itupun

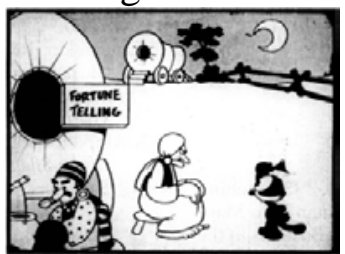

Gb 26 banyak meraih perhatian penonton. Sullivan juga menjadi pelopor dalam penggunaan produk tie-in seperti boneka untuk lebih mengeksploitasi kesuksesan karakter kartunnya. Seperti sebagian besar serial animasi yang penting lainnya di tahun 1920-an, Felix tidak terbangun dengan baik pada era film bersuara, meskipun begitu nyatanya ada banyak imitasi yang di kemudian hari muncul dari karakter tokoh Felix ini. 
Dorongan industri film AS ke pasar luar negeri selama Perang Dunia I memberinya basis ekonomi yang sangat besar untuk melakukan ekspansi dan konsolidasi selama tahun 1920an. Sebagian besar industri film nasional di luar terlalu kecil untuk memberikan perlawanan yang signifikan terhadap dominasi Amerika. Namun sinema terus menjadi fenomena internasional, dan banyak negara. Sebenarnya beberapa negara di Eropa cukup kuat untuk mendukung industri film nasional mereka dan bahkan mempertimbangkan untuk bersatu agar dapat menantang kekuatan Amerika. Terlebih lagi, untuk pertama kalinya, pembuat film di beberapa negara telah menciptakan film-film eksperimental pendek dengan pendekatannya yang berbeda sebagai upaya menantang pendekatan naratif klasik sinema Hollywood.

\section{SIMPULAN}

Animasi merupakan bagian dari Film. Meskipun dalam keilmuannya, animasi dapatlah berdiri sendiri, sehingga dibutuhkan sejarah film animasi guna keilmuan film animasi. Meski hanya berupa sejarah film animasi yang ditujukan pada film-film animasi berdurasi pendek, namun pada kenyataannya jika melihat periode awal film, durasi pendek itu sendiri sudah merupakan film panjang, seperti halnya film-film yang di produksi oleh Lumiere Bersaudara, ataupun George Melies dan lain sebagainya.

Pada akhirnya, film animasi setidaknya memiliki catatan sejarahnya yang dapat dipelajari agar memahami karya-karya film animasi yang merupakan proses hingga terbentuknya karya film animasi saat ini. Adapun dengan mengetahui karya-karya film animasi yang masuk kedalam catatan sejarah, kiranya dapatlah menjadi referensi saat mengkaji ataupun membuat film animasi.

Sumber:

Bordwell, David and Kristin Thompson. Film History, 2:52; McGraw-Hill Companies, Inc-New York, 2008.

Dixon, Wheeler Winston, and Gwendolyn Audrey Foster. A Short History of Film, 1:19; Rutgers University press- New Jersey, 2008.

Cooper dan Taylor dalam Mohammad Imam Farisi. 2010. Pengembangan Asesmen Diri Siswa (Student Self-Assessment) sebagai Model Penilaian dan Pengembangan Karakter. Artikel disampaikan pada Konferensi Ilmiah Nasional "Asesmen dan Pembangunan Karakter Bangsa” HEPI UNESA 2012.

Louis O. Katsoff dalam Yuni Irawati. 2013. Metode Pendidikan Karakter Islami Terhadap Anak Menurut Abdullah Nasih Ulwan dalam Buku Pendidikan Anak dalam Islam dan Relevansinya dengan Tujuan Pendidikan Nasional. Skripsi tidak diterbitkan. UIN Sunan Kalijaga. h.26.

Quoted in Yuri Tsivian et aI. Silent Witnesses: Russian Films 1908-1919 (London: British Film Institute, 1989), p. 586.

Quoted in Walter Schobert, The German Avant-Garde Film of the 1920's (Munich: Goethe-Institut, 1989), p. 10 in Bordwell.

From the New York Times, quoted in Donald Crafton, Before Mickey: The Animated Film 1898-1928 (Cambridge, MA: MIT Press, 1982), p.174.

https:/tvtropes.org/pmwiki/pmwiki.php/UsefulNotes/TheHaysCode 12 April 2020 pukul 11.44 wib. The Hays Code adalah nama informal untuk The Motion Picture Production Code, yang diadopsi pada tahun 1930 tetapi tidak ditegakkan secara serius sampai tahun 1934. Kode ini adalah seperangkat aturan yang mengatur pembuatan film Amerika yang membentuk -dan dalam banyak hal menghambat- bioskop Amerika selama lebih dari tiga dekade. 
Gb 1. https://www.timesindonesia.co.id/read/225348/20190816/075226/sambut-hut-ke74-ri-hotel-tugu-malanggelar-wayang-kulit-gathotkaca-kridha/, 16 Agustus 2019 pukul 24.15 wib

Gb 2. https://www.fredaldous.co.uk/blogs/news/analogue-photography-point-shoot-develop 16 Agustus 2019, pukul 23.45 wib.

Gb 3. Kernan, Brian Mc. "Digital Cinema: Revolution in Cinematography, Postproduction, and Distribution". McGraw-Hill Companies Inc. USA, 1976.

Gb 4. https://tirto.id/kamar-gelap-ibn-al-haytham-dan-lahirnya-kamera-cpq6, 16 Agustus 2019, 24.00 wib.

Gb 5. http://thelifetimephotography.blogspot.com/2011/08/from-camera-obscura-to-instamatic.html 17 Agusutus 2019 pukul 24.05 wib

Gb 6. https://www.fredaldous.co.uk/blogs/news/analogue-photography-point-shoot-develop 16 Agustus 2019, pukul 23.45 WIB.

Gb7. https://steemit.com/food/@charlotteblacker/animated-cakes-and-turn-tables-the-art-of-zoetrope-animation

9 Februari 2021 pukul 15.18 wib

Gb8. https://www.wikiwand.com/en/Charles-\%C3\%89mile_Reynaud 8 Februari 2021 pukul 22.23 wib

Gb 9. https://www.ssplprints.com/image/87391/lumiere-cinematographe-1895 9 Februari 2021 pukul 15.31 wib

Gb 10. https://en.wikipedia.org/wiki/The Haunted_Hotel 9 Februari 2021 pukul 15.15wib

Gb 11. https://www.youtube.com/watch?v=-rTPt9qDViI 9 Februari 2021 pukul 15.38wib

Gb 12, 13, 15-32, Bordwell, David and Kristin Thompson. Film History, 2:52; McGraw-Hill Companies, IncNew York, 2008.

Gb 14 Dixon, Wheeler Winston, and Gwendolyn Audrey Foster. A Short History of Film, 1:19; Rutgers University press- New Jersey, 2008. 